\title{
IMAGINING AND RATIONALLIZING OPPORTUNITIES: INDUCTIVE REASONING AND THE CREATION AND JUSTIFICATION OF NEW VENTURES
}

\author{
JOEP P. CORNELISSEN \\ JEAN S. CLARKE \\ University of Leeds
}

\begin{abstract}
We argue that creating novel ventures consists of inductive analogical or metaphorical reasoning, which generates a platform for the creation and commercialization of novel ventures and facilitates the comprehension and justification of a venture. We argue that such inductive reasoning is shaped by two determinants (the applicability of prior entrepreneurial experience and the motivation to resolve uncertainty and acquire legitimacy) that interrelate to predict and explain patterns of analogical and metaphorical reasoning by which novice and experienced entrepreneurs construct meaning for themselves as well as others in the early stages of creating a venture.
\end{abstract}

The creation of new ventures is a process by which entrepreneurs come to imagine the opportunity for novel ventures, refine their ideas, and, after an initial investment, justify their ventures to relevant others to gain much-needed support and legitimacy (e.g., Alvarez \& Barney, 2007; McMullen \& Shepherd, 2006). Yet how do entrepreneurs come to create and justify new ventures in such a way that they acquire institutional legitimacy and the necessary resources for venture growth? Despite on increase in conceptualizing and specifying the process of entrepreneurship (e.g., Zott \& Huy, 2007), research has not fully addressed this question, with most accounts theoretically or empirically equating the process with antecedent cognitive scripts or characteristics of entrepreneurs (e.g., Baron \& Ensley, 2006; Busenitz \& Barney, 1997; Shane, 2000) or with performance outcomes and the achievement of legitimacy in an industry (Aldrich \& Fiol, 1994; Starr \& MacMillan, 1990). However, equating entrepreneurship with such antecedents or outcomes overemphasizes either the individual and his or her present cognitive state or the configuration of the social context and institutional outcomes, at the expense of a more integrative under-

We thank our colleagues for helpful comments on an earlier draft. We are especially grateful to associate editor Adelaide King and three anonymous reviewers for their valuable comments and encouragement. The usual disclaimer applies. Both authors contributed equally to this article. standing that embeds individual entrepreneurs within their social contexts (e.g., Garud \& Karnøe, 2003; McMullen \& Shepherd, 2006).

We argue that a sensemaking approach (e.g., Taylor \& Van Every, 2000; Weick, 1995), which emphasizes a direct relationship among the language, cognition, and enactment of entrepreneurs, may help develop a combined cognitive and symbolic conception of the process by which the idea for a novel venture is imagined, refined, and justified to others. Adopting this approach, we elaborate theory on how individual entrepreneurs use certain forms of speechspecifically, analogy and metaphor-to induce an opportunity for a novel venture. They use these devices too while speaking to relevant others, such as employees and (prospective) investors, in order to acquire needed capital and support to make those ventures succeed (Alvarez \& Barney, 2007; Hill \& Levenhagen, 1995).

Specifically, we aim to make a number of contributions. First, we conceptualize processes of inductive analogical and metaphorical reasoning supporting the creation and justification of novel ventures. Despite the recognized importance of induction in entrepreneurship (e.g., Baron \& Ward, 2004), little theory or research in entrepreneurship exists on when, how, and why entrepreneurs use inductive reasoning (Ward, 2004) to move beyond their current understanding and produce novel ventures (Baron \& Ward, 2004). Second, we develop a process theory of

Copyright of the Academy of Management, all rights reserved. Contents may not be copied, emailed, posted to a listserv, or otherwise transmitted without the copyright holder's express written permission. Users may print, download, or email articles for individual use only. 
new venture creation that specifies two determinants: (1) the availability and applicability of prior entrepreneurial experience and (2) the motivation to resolve uncertainty and to gain legitimacy for novel ventures. These determinants interrelate to predict and explain patterns of inductive reasoning by entrepreneurs in the early stages of creating a venture (i.e., the stages of initial exploration, planning, and launch). Third, we combine and reconceptualize the predictions of theory on entrepreneurial cognition (e.g., Mitchell, Busenitz, Lant, \& McDougall, 2002) and institutional legitimacy (e.g., Lounsbury \& Glynn, 2001) in our process theory. We go on to offer a pragmatic and conceptual approach to the difficult task of bridging the related but largely separate cognitive literature and institutional literature on entrepreneurship. Fourth, the process theory we propose provides a methodological contribution: it can be readily connected to the sophisticated techniques developed in linguistics and discourse analysis (e.g., Putnam \& Fairhurst, 2001) for analyzing shifts and changes in how entrepreneurs inductively reason about novel ventures. These techniques make it possible to complement the study of entrepreneurial cognition or institutional effects with empirical studies of how entrepreneurs-through moment-by-moment communication and interaction with others-come to envision, refine, and justify ideas for a novel venture.

In the paper we focus on the development of independent new ventures that are not sheltered by sponsoring organizations (e.g., spinoffs). By definition, such ventures are associated with high levels of uncertainty; this forces the entrepreneur to make the enterprise comprehensible and meaningful to key stakeholders. Throughout the article we refer to new ventures as commercial enterprises that are imagined and rationalized by an entrepreneur in relation to specific emerging or established markets and industries.

We present our arguments as follows. We provide an overview of past cognitive and institutional research on entrepreneurship and propose and develop an alternative perspective, grounded in sensemaking, that we believe integrates and extends our understanding of the creation and legitimization of new ventures. We then develop a specific model of new venture creation, integrating predictions from entrepre- neurial cognition and institutional theory. Finally, we discuss the implications of this model for the study of entrepreneurship and new venture creation and end with specific recommendations for empirical research.

\section{NEW VENTURE CREATION}

The study of new venture creation primarily has been addressed in two related yet largely separate bodies of literature. The first, generally referred to as the cognitive perspective, has focused on the cognitive characteristics of individual entrepreneurs and the possession of prior knowledge as the primary basis for identifying and designing new ventures (e.g., Baron, 2000; Busenitz \& Barney, 1997; Grégoire, Corbett, \& McMullen, in press; Shane, 2000). When entrepreneurs make sense of market opportunities and the possibility for a new venture, scholars see this as largely an individual cognitive process. Scholars subsequently subdivide their attention among different features of this process, such as an entrepreneur's perceptual noticing and bracketing of breaks in his or her experience and the richness and specificity of the entrepreneur's cognitive prototypes, scripts, or mental models (i.e., cognitive frameworks acquired through experience; Baron \& Ensley, 2006; Korunka, Frank, Luegar, \& Mugler, 2003; Krueger, Reilly, \& Carsrud, 2000). For example, when entrepreneurs gain repeated experiences within certain markets or in the development of ventures, they build richer and more specific mental models or scripts of their environment (e.g., Baron \& Ensley, 2006; Grégoire et al., in press; Mitchell, Smith, Seawright, \& Morse, 2000). They can then draw on or cognitively extend such mental models or scripts to new situations and, in the process, identify the opportunity for a new venture.

A main limitation of this cognitive perspective is that it at times treats the individual entrepreneur in isolation from his or her social environment, and it is unable to capture or explain how entrepreneurs are creative and how, through inductive reasoning, they may imagine or create novel opportunities that surpass their past (cognitively accumulated) experiences (Baron \& Ward, 2004). The main reason for this is that cognitive scripts or mental models provide by themselves no rules or guidelines for the interpretation of and inductive reasoning about 
novel circumstances (Edwards, 1997; Weick, 1995). Within the cognitive perspective, an entrepreneur's speech is also seen as "revealing" cognitive interpretations (Donnellon, 1986; Gioia, 1986); when entrepreneurs label and articulate their experiences while communicating to others, they externalize or express "some neutral, definitive and ready-made sense of events produced through a process such as noticing what the world is like and then putting it into words" (Edwards, 1997: 144). Accordingly, the cognitive perspective focuses on individual modes of thought without speech and outside a social context, casting aside the formative effect of language, particularly online speech, on thought processes and the construction of meaning (e.g., Fauconnier, 1997; Langacker, 1991).

A second body of literature, under the broad heading of institutional theory, has located entrepreneurship within a social context and has focused on cultural and symbolic realms of meaning construction around new ventures (e.g., Lounsbury \& Glynn, 2001; Martens, Jennings, \& Jennings, 2007; Zott \& Huy, 2007). Given that most new ventures lack proven track records, obvious asset value, and profitability, entrepreneurs are forced to draw on a common discourse to construct accounts that help explain, rationalize, and promote a new venture and increase its perceived legitimacy in the eyes of resource providers (Aldrich \& Fiol, 1994; Lounsbury \& Glynn, 2001). The discourse (e.g., frames, codes, and myths) that individual entrepreneurs use in this process is viewed as an outgrowth of social categories and social processes of disseminating and sharing information (Putnam \& Fairhurst, 2001; Weber, 2005). Zilber (2006) and Weber, Heinze, and DeSoucey (2008), for example, show how entrepreneurs in social movements and high-tech ventures enlisted cultural codes and myths to create "cultural resonance" between their specific framing of a venture and the broader value orientations of stakeholders. The institutional tradition highlights a sociolinguistic focus (Putnam \& Fairhurst, 2001) on how the specific speech of entrepreneurs evokes salient cultural codes or frames that encode the criteria for institutional legitimacy by appealing to collective shared understandings and norms for how novel ventures are sensible, acceptable, and legitimate (Aldrich \& Fiol, 1994; Rao, 1994; Zott \& Huy, 2007).
A main limitation of the institutional tradition is that it does not connect to the material context in which entrepreneurs create or identify opportunities for novel ventures. In addition, insofar as it treats social structures as relatively stable and it assumes fixed, socially shared linguistic repertoires (Putnam \& Fairhurst, 2001), institutional theory is also unable to explain how individual entrepreneurs pragmatically and creatively make sense of the world around them on particular occasions (Weick, Sutcliffe, \& Obstfeld, 2005). Within the broader institutional literature, this limitation is reflected in concerns about studies of institutionalization that focus almost exclusively on established conventions, codes, and symbols and how these are being translated, enlisted, or evoked in local contexts (e.g., Phillips, Lawrence, \& Hardy 2004). The underlying assumption is that, once internalized, the social competence of individuals in speaking a (socially shared) language will subsequently act "as internalized cognitive constraints on sensemaking" (Weber \& Glynn, 2006: 1640). In other words, speech is socially conditioned and constrained and is largely reproduced in a rote, habitual manner without conscious thought.

We argue that the respective foci and limitations of both traditions suggest they are complementary: the cognitive tradition stresses the internal, self-conscious, and cognitive process of entrepreneurs' developing an account of what is going on, while the institutional tradition emphasizes the external, strategic process of evoking meaning in line with political interests. It thus appears that much may be gained from moving toward an approach that sees entrepreneurial actions and new venture creation as not exclusively the outcome of either cognitive processes or of processes "in the sphere of symbolic codes" (Bartholomew \& Mayer, 1992: 152).

\section{SENSEMAKING AND ENTREPRENEURIAL ACTION}

To establish such an approach, better linking the individual entrepreneur with the social context, we draw on the broad perspective of sensemaking (Hill \& Levenhagen, 1995; Weick, 1995). Within the context of entrepreneurship, Hill and Levenhagen (1995: 1057) argue that entrepreneurs "operate at the edge of what they do not know" and must seek to make equivocal events 
nonequivocal by constructing a new vision of the business environment (Alvarez \& Barney, 2007). In the early stages of creating a new venture, entrepreneurs also need to speak to others about this vision in order to gain feedback and their support (Lounsbury \& Glynn, 2001). Hill and Levenhagen (1995) propose that such visions and the opportunities that they imply may be perceptually or unconsciously "felt" but are configured into more elaborate presentations when they are verbally articulated.

We take as a starting point Hill and Levenhagen's (1995) view that the formative effects of language on thought processes (e.g., Langacker, 1991) need to be incorporated and theorized in the context of entrepreneurial action and new venture creation. While the inner thoughts and imaginations of entrepreneurs matter, they are not spoken or even necessarily speakable; to get to speech, something further takes place, and this is what we term sensemaking. Functionally, sensemaking occurs at the point where new (verbal) ideas take form in the stream of the entrepreneur's experience, with external speech reconfiguring ideas to fit the demands of spoken language. Sensemaking, in other words, is an act of turning circumstances "into a situation that is comprehended explicitly in words and that serves as a springboard to action" (Taylor \& Van Every, 2000: 40; see also Weick et al., 2005: 409).

Sensemaking implies that the world does not present itself in a direct or "row form," but, rather, entrepreneurs actively construct it using available linguistic frames, including prefabricated vocabularies (Weber, 2005) that become elaborated in a coherent way, thus shaping thinking while speaking. Although sensemaking has often been considered as retrospective (e.g., Weick et al., 2005), it may also be prospective in the context of new ventures and "aimed at creating meaningful opportunities for the future" (Gioia \& Mehra, 1996: 1229). Entrepreneurs, for example, are likely to rearrange or blend words creatively in the form of analogies or metaphors in their speech; this allows them to imagine future opportunities and to make those opportunities understood by others (Hill \& Levenhagen, 1995; Lounsbury \& Glynn, 2001).

Sensemaking is also a dynamic process, with the social context of speaking and interactions with others affecting the construction of meaning about a new venture (Slobin, 1987; see also
Alvarez \& Barney, 2007, and Hill \& Levenhagen, 1995). Within this process, thought and language are intimately and dynamically connected at the point where entrepreneurs verbalize their experiences and elaborate these in a context of speaking to others. Baker, Miner, and Eesley's (2003) study of entrepreneurial start-ups provides an example of this process. Their study shows that the design and implementation of new start-ups was not only "psychological or driven by internal needs" but was also significantly "driven by exogenous demands by external resource providers for founders to provide accounts that make their firms appear like legitimate investment opportunities, suppliers or customers" (2003: 264). The result was an improvisational process, with the design and implementation of these ventures emerging at least in part from verbal interactions with resource providers.

The crucial point here is that the social context interacts with processes of language use and cognition. We therefore cannot draw too sharp a distinction between sensemaking for oneself and sensegiving to others (Tetlock \& Manstead, 1985). Once entrepreneurs communicate with others, these instances already integrate social pressures for persuasion and justification with linguistic and cognitive processes of sensemaking. While this is a general feature of online processes of meaning construction (Fauconnier, 2000), it has been largely lost in the general body of sensemaking research (e.g., Weick, 1995; Weick et al., 2005; for a comprehensive review see Maitlis \& Sonenshein, 2010), where individual cognition (sensemaking) is typically divorced from symbolic processes of influence and impression management (sensegiving) in social settings.

Our goal here is to favor neither cognitive accounts (that see an entrepreneur's sensemaking and action in context as derived from and determined by cognitive interpretations) nor symbolic accounts (that see it as largely conditioned and bounded by the discursive fields or communities in which entrepreneurs operate). Instead, we aim to conceptualize how language and thought interpenetrate in context and how meaning is not fixed but continually developing as a result of interactions with others. Such an approach does not deny agency or structure but shifts attention to individual acts of sensemaking around the early stages of new venture cre- 
ation. Specifically, we conceptualize how, through analogical and metaphorical reasoning, entrepreneurs not only imagine new ventures that surpass their past experiences but also, through such reasoning, attempt to establish shared understanding, support, and legitimacy for their burgeoning ventures. In the initial stages of a venture, entrepreneurs make sense of opportunities for novel ventures by setting these apart from what already exists while locating their ideas within stakeholders' existing understandings in order to gain acceptance and support (Hargadon \& Douglas, 2001; Santos \& Eisenhardt, 2009). A sensemaking approach, therefore, bridges the established cognitive and institutional traditions in that it sees language as not simply an extension or representation of cognitively recorded experiences but as actually formative of thought and, hence, as a resource that individuals use to create or produce a common understanding of new ventures.

A central assumption underlying our theorizing is that individual entrepreneurs are "theorists of a pragmatic sort" (Strang \& Meyer, 1993; Tetlock, 2000; Weick, 1995). They self-consciously and through verbal interactions with others develop notions about cause and effect, thus "theorizing" their world and the relationships and opportunities within it (Alvarez \& Barney, 2007; Tetlock, 2000). At the individual level, entrepreneurs may be viewed as intuitive scientists, engaged in a continuous struggle to achieve cognitive mastery of their world (Sarasvathy, 2004), or as intuitive economists, using the resulting cognitive representations to identify courses of action that advance, if not maximize, their interests (McMullen \& Shepherd, 2006). In a social context entrepreneurs may be seen as intuitive politicians (Alvarez \& Barney, 2007) or cultural operators (Rao, 1994; Zott \& Huy, 2007) who seek to be accountable to different social groups and whose choices and judgments are embedded in and constrained by the "broader social and cultural dynamics that embed start-ups" (Lounsbury \& Glynn, 2001: 546). These different individual-cognitive and social-cultural images of entrepreneurs are, as mentioned, not conceptually incompatible. In fact, some key works in the cognitive and institutional traditions acknowledge or implicitly assume that the individual and social realms can be bridged ( $\mathrm{Di}$ Maggio, 1997; March \& Olsen, 1989). In this article we similarly attempt to embed individual entrepreneurs in social contexts that surround new venture creation.

\section{INDUCTION AND NEW VENTURES}

In this section we theorize how, in social contexts of speaking, entrepreneurs use inductive reasoning to create a meaningful opportunity for a novel venture and attempt to convince others of that opportunity in order to gain muchneeded support. We first provide an introduction to the key concepts of analogy and metaphor as primary forms of inductive reasoning. Through such reasoning entrepreneurs verbally create a hypothetical world in which they highlight discursive objects to themselves and others (Quinn \& Dutton, 2005). A discursive object is a noun or noun equivalent in a propositional phrase that can refer to a physical or material entity (e.g., a technological innovation) or a symbolic entity (e.g., a societal role for a new venture).

Although we focus exclusively on verbal acts of sensemaking, we acknowledge that material circumstances and objects may trigger or anchor verbally produced conceptual images or scenarios for a venture (e.g., Hutchins, 2005), but this is beyond the scope of this paper. Also, while we do not address the specific ways in which the material environment or physical objects may prime or anchor entrepreneurial sensemaking, Baker and Nelson (2005) and Denrell, Fang, and Winter (2003) demonstrate that this is accomplished through a correspondence between conceptualizations expressed in words and potential or realized combinations of physical resources.

\section{ANALOGICAL AND METAPHORICAL REASONING}

When entrepreneurs perceptually sense or feel that there may be an opportunity for a venture in a particular industry, they make that opportunity intelligible to themselves and others through inductive reasoning (Hill \& Levenhagen, 1995). Because no entrepreneur, however prescient, can see into the future or know with certainty how decisions and actions will pan out, they necessarily rely on inductive reasoning for this purpose. By inducing images or scenes of how new ventures are likely to function in an industry and grow, or, alternatively, of how entrepreneurs want them to function and 
grow, entrepreneurs as well as relevant others (e.g., investors and employees) achieve some ability to comprehend the opportunity for a venture and the future consequences of decisions and actions.

Specifically, the literature on induction (e.g., Gentner, Bowdle, Wolff, \& Boronat, 2001; Holland, Holyoak, Nisbett, \& Thagard, 1986; Nisbett \& Ross, 1980) generally explicates how using analogies or metaphors - that is, verbally referring to other cases and domains of experiencecon guide thinking and create understanding and social acceptance. It suggests that entrepreneurs may invoke analogical or metaphorical comparisons with other cases and experiences to fomiliarize themselves and others with a new venture, to reduce uncertainty, and to support further inferences (e.g., Lounsbury \& Glynn, 2001; Sternberg, 2004; Ward, 2004). Analogies and metaphors are useful in this context because they "convey relationships to concepts already understood ... [and hence] facilitate the construction of meaning by the person or group experiencing them" (Gioia, 1986: 53). As part of sensemaking, analogies and metaphors give structure, allowing entrepreneurs to make sense of puzzling or unfamiliar situations (e.g., Gioia, 1986; Gioia, Thomas, Clark, \& Chittipeddi, 1994), and produce links to action by virtue of the inferences for action that they evoke (e.g., Gioia, 1986; Weick, 1995). Besides structuring situations into an understandable format, analogies and metaphors also socially justify decisions and actions to others (Creed, Langstraat, \& Scully, 2002) by validating some accounts and discrediting or preempting others (e.g., Rindova, Becerra, \& Contrado, 2004; Weick et al., 2005).

Strictly speaking, analogies and metaphors are verbally drawn similarities with other cases and experiences that are either directly extended to a new venture situation (as the target) or elaborated in interaction with the target as a basis for inferences (e.g., Gentner et al., 2001). The difference between analogies and metaphors rests in the literal versus figurative nature of the comparison (Fauconnier \& Turner, 1998, 2002). Analogies, in the context of new ventures, involve literal references to cases and observations associated with entrepreneurship, market, or industry contexts, and ventures and businesses in general. An analogy, in other words, conjoins cases from the same category of observations (e.g., Gavetti, Levinthal, \& Rivkin, 2005;
Terlack \& Gong, 2008). Metaphors, on the other hand, refer to figurative-and hence crosscategorical-comparisons (Cornelissen, 2005; Lakoff, 1993), where the creation of a new venture is likened to cultural domains of experience (e.g., parenting, sports, and warfare) outside a specific entrepreneurial or business context (Cardon, Zietsma, Saparito, Matherne, \& Davis, 2005; Rindova et al., 2004). As a result, the new venture in a particular industry is not simply represented to be as or like other ventures or industries (as in the case of analogies) but as if it resembles in some form a literally unrelated but culturally formiliar domain of experience.

The specific analogies and metaphors that entrepreneurs use can be already familiar and conventional or wholly novel and creative (Cornelissen, 2005). Entrepreneurs may simply extend conventional analogies or metaphors in their speech to the new venture situation as the target. This kind of induction is known as a projection-first model (Gentner et al., 2001), since the analogical or metaphorical reasoning involves the direct projection of an entrenched description of a source domain onto a target domain, after which it is corrected and adjusted to the target (see also Cardon et al., 2005; Farjoun, 2008; Gavetti et al., 2005: 696). Entrepreneurs may also draw novel analogical or metaphorical comparisons in relation to a new venture (e.g., Baker \& Nelson, 2005). This kind of induction is known as an alignment-first model, since entrepreneurs discursively align the source and target and elaborate the comparison, before any likely inferences can be drawn from the source to the target (e.g., Fauconnier, 1997; Gentner et al., 2001). Alignment-first models are creative and may deliver emergent inferences that, when evaluated and verified in relation to the target of a novel industry, may turn out to be credible and useful (Cornelissen, 2005; Sternberg, 2004).

The use of analogies or metaphors in relation to new ventures is, we argue, conditioned by the degree to which an entrepreneur has had previous experiences in and has learned about the same or similar industries in which the new venture will be based (Shane, 2000, 2003). It is also conditioned by the activation of social pressures to demonstrate the predictability and legitimacy of a venture to stakeholders (Aldrich \& Fiol, 1994; Lounsbury \& Glynn, 2001). These two determinants influence the extent to which as 
well as how an entrepreneur uses analogical or metaphorical reasoning during the initial stages of exploring ideas and planning and launching a venture. Indeed, in the initial stages of a venture, entrepreneurs squarely rely on analogical and metaphorical reasoning to create the opportunity for new ventures and to set these apart from what already exists while locating their ideas within stakeholders' existing understandings in order to gain acceptance and support (Hargadon \& Douglas, 2001; Santos \& Eisenhardt, 2009). After the launch, and when the venture achieves a turnover and early growth as indicators of its profit-making ability (Hite \& Hesterley, 2001; Zimmerman \& Zeitz, 2002), entrepreneurs generally become less reliant on inductive reasoning. Instead, they may shift to more calculated reasoning that is based on direct experiences and the performance of the new venture in its industry (Aldrich \& Fiol, 1994; Hargadon \& Douglas, 2001; Hill \& Levenhagen, 1995).

In the next section we unfold these arguments and illustrate our main propositions with case examples of novel ventures in nascent markets that emerged through the confluence of the computing, electronics, and telecommunication industries in the mid 1990s (Santos \& Eisenhardt, 2009). Santos and Eisenhardt's (2009) original study described how entrepreneurs framed the existence of novel markets and subsequently signaled the leadership and feasibility of their ventures in these markets. We shed new light on their cases by demonstrating how they exemplify the main inductive processes and determinants within the initial stages of venture creation.

\section{PRIOR EXPERIENCE AND INDUCTIVE REASONING}

Goodman (1955) gave a well-known account of the basis of inductive reasoning-one pointing toward the historical practices and experiences of entrepreneurs, particularly their language use rather than simply their psychology (Sloman \& Lagnado, 2005). He claimed that induction may consist of a mental habit formed by past observations and experiences but that language is driving whatever past regularities are selected and thus projected onto a novel or future situation. Goodman (1955) specifically argued that the entrenchment of language affects inductive reasoning. In short, entire verbal descriptions or specific words are entrenched when they and their metaphorical extensions have historically figured in this usage.

Applied to entrepreneurship, this means that through depth of experience in or through learning about one or multiple industries, entrepreneurs may have entrenched descriptions of the key features driving success or performance in a particular industry (e.g., Baron \& Ensley, 2006; Gavetti et al., 2005; Haunschild \& Miner, 1997). For example, based on depth of experience in the media industry, an entrepreneur may verbally describe the industry as one where "advertising is key because intrinsic product quality is hard to assess, and therefore customers' taste is easily shapeable" (Gavetti \& Warglien, 2007: 7). Depth of experience refers to the time spent by an entrepreneur operating in or learning about a particular industry (Gavetti et al., 2005). The principle of entrenchment suggests first of all that those entrepreneurs with depth of experience in industries deemed relevant to the new venture will refer to their past descriptions of those industries and will analogically project these onto the novel venture as a working hypothesis. This also implies that novice entrepreneurs or those without experience in relevant industries do not have any direct analogies to hand and therefore face a clear sensemaking imperative (Santos \& Eisenhardt, 2009; Sarasvathy, 2004). As a consequence, these entrepreneurs are likely to draw on entrenched, idiomatic words or expressions in their speech that they metaphorically extend to the new venture as a way of creating understanding for themselves and others (e.g., Cardon et al., 2005; Dodd, 2000; Nicholson \& Anderson, 2005). Specifically, we argue that in the absence of directly relevant prior experiences and observations, entrepreneurs will induce metaphors to suggest an opportunity and to construct a basic scenario for the creation and commercialization of a new venture in an unfamiliar industry (Hill \& Levenhagen, 1995; Sarasvathy, 2004). This leads to our first proposition.

Proposition 1: The degree to which entrepreneurs have depth of experience in industries related to the target industry for the new venture is associated with the use of analogies (presence) or metaphors (absence) when 
they are initially speaking to others about the venture.

In addition, those entrepreneurs with prior experience may also have a certain breadth of experience in that they have observed or learned about different industries. Combining breadth with depth of experience means that some entrepreneurs have fully developed verbal descriptions that distinguish multiple industries on the basis of significant features, such as, for example, the size of economies of scale, the size of customer switching costs, and the heterogeneity of customer tastes (Farjoun, 2008; Gavetti et al., 2005). Where entrepreneurs indeed have depth and breadth of experience in multiple industries, we argue that they are likely to refer to those descriptions of industries that are causally specific and include multiple features, as opposed to descriptions built around features that are isolated or generally less entrenched (cf. Goodman, 1955).

Gentner highlights, in this respect, the preferred use of relational analogies, where there is "an assertion that a relational structure that normally applies in one domain can be applied in another domain" (1983: 156). The emphasis here is on the relationships between features in the relevant source domain and their underlying causality, as opposed to analogies that simply highlight common features between industries (Gentner \& Clement, 1988; Gentner et al., 2001).

Where entrepreneurs have access to multiple such causal descriptions for relational analogies, Goodman (1955) predicts that the entrenchment (i.e., repeated mention) of parts of such descriptions (e.g., around economies of scale and customer tastes) determines the likelihood of their use. A good example of these principles is the case of Magic, a venture based on "customer-centric online shopping" (Santos \& Eisenhardt, 2009: 650). When the venture was founded, online shopping was a novel concept and one that was poorly understood. There was confusion about basic elements of the service, including how to evaluate products and how to make payments (Santos \& Eisenhardt, 2009: 650). The entrepreneur behind Magic who faced these challenges coined the analogy of seeing online shopping like (offline) retailing-specifically, like the experience of supermarket shopping-an image that provided a clear model for the new venture. The user interface, for exam- ple, became based on such concepts as "selfservice," "shopping cart," and "checkout." This analogy also led to the inference that the entrepreneur needed to provide the world's widest selection in its product category-an insight stemming from the source image of a selfservice retail shop selling a wide range of products and services with economies of scale in the supply chain (buying, checkout selling points, and self-service).

The induction of the retail supermarket image in this example suggests that entrepreneurs do not import random facts or features from a source to a target but instead prefer to project inferences that build on a whole set of relations that can be discursively projected to or aligned with a target domain (cf. Gentner \& Clement, 1988). The retailing domain was also intimately familiar to the founding entrepreneur and Magic executives. Retailing concepts had already been an established part of their vocabulary while speaking to each other (cf. Goodman, 1955). This leads to the following proposition.

\section{Proposition 2: Entrepreneurs with depth and breadth of experience in multiple industries are likely to in- duce analogies that highlight a com- mon set of relations between on (ex- perienced or observed) industry and the target industry when they are ini- tially speaking to others about a novel venture.}

As mentioned, entrepreneurs with a lack of prior industry experience need to draw on idiomatic words and expressions metaphorically to create meaning, reduce uncertainty, and prescribe a course of action (e.g., Gioia, 1986; Hill \& Levenhagen, 1995). In this circumstance entrepreneurs will initially be primed, we argue, to draw upon basic argument constructions because these are entrenched in language use in general (Goldberg, 1995). Argument constructions include grammatical forms with a subject and operative verb, such as to give (the ditransitive construction-i.e., where the verb can take a direct and indirect object); to make or to cause (the resultative construction); or to move, to go, or to enter (the caused motion construction). These constructions are prime material for metaphorical reasoning and "encode as their central senses event types that are basic to human experiences" (Goldberg, 1995: 39). For example, 
entrepreneurs often refer to "leveraging" a client base, "building" market awareness, "expanding" market share, "acquiring" market acceptance (Martens et al., 2007: 1118), "getting new customers," or "making it happen" (Sarasvathy, 2004). In this way they metaphorically suggest that they can physically manipulate and control markets as if these were objects.

The entrenchment of argument constructions-and their preferred use for metaphorical induction-is consistent with Lakoff and Johnson's $(1980,1999)$ embodiment hypothesis. The basic hypothesis is that the inductive creation of metaphorical meaning is directed and constrained in that individuals choose from a finite number of semantically autonomous argument constructions and their associated embodied source domains (i.e., human motor actions involving physical movement or physically holding or manipulating an object).

A good example of this thesis is the case of Secret, another venture studied by Santos and Eisenhardt (2009). Secret's founders began with a sophisticated cryptography technology but without a clear model of the venture or a welldefined product or market in mind. They experimented with several ideas while talking to each other and started to focus on the development of a security product in the context of digital communications. One executive honed in on the notion of trust, which he described as "not just security in terms of keeping people out but it also was letting people in" (Santos \& Eisenhardt, 2009: 649; emphasis added). The basic metaphorical image of the controlled movement of people in and out of a system provided the impetus for the new venture and defined the product in comparison to standard security technology focused on restricting access. Secret's executives therefore emphasized trust as central to the new venture's identity and its product. However, ambiguity in the market remained, prompting them to adopt additional metaphors to describe their venture for would-be customers and other stakeholders, as well as for themselves (Santos \& Eisenhardt, 2009: 649). To emphasize the product's ability to support and control legitimate movements in digital communications, they shifted to a metaphor of border control. According to Santos and Eisenhardt, "They used well-known terms such as 'ID card,' 'wallet,' and 'passport' as part of their vocabulary" (2009: 649). This particular framing gained acceptance, as illustrated by the following quote from Secret's venture capital backer: "You know, you have kind of an electronic wallet and have all your IDs on one thing, and it would become your passport around the net" (Santos \& Eisenhardt, 2009: 649).

As this example illustrates, the default induction of argument constructions may be corrected or adjusted when entrepreneurs speak to stakeholders and gain feedback, a point that we will return to below. For now, it is important to highlight that such a correction or adjustment process is likely to operate as a gradual process (Epley \& Gilovich, 2006). Based on the plausibility of the communicated image for the venture and the ambiguity in the market, an adjustment away from the default inductive base is made until a satisfactory solution is reached (Goodman, 1955). Specifically, this means that default basic argument constructions (such as the caused motion construction of people moving in and out of a digital system) are primed for metaphorical induction and will initially be adjusted with further information on cultural domains, such as, for example, border control (Santos, \& Eisenhardt, 2009) or, alternatively, engineering (Sarasvathy, 2004), parenting (Cardon et al., 2005), theater, or warfare (Dodd, 2000; Nicholson \& Anderson, 2005). These cultural domains still include concrete, embodied activities, but their adjustment involves further detail on the culturally specific context of such activities that may resonate with stakeholder expectations and understandings (Hannan, Pólos, \& Carroll, 2007). When such anchoring in further cultural knowledge is still unsatisfactory in terms of stakeholder comprehension and support, the correction process continues and shifts, as we explain below, toward alternative cultural metaphors that have a history of use but may be a move away from the initial basic argument constructions (Epley \& Gilovich, 2006). However, in the initial stages of $a$ venture, we expect the default induction of argument constructions that are metaphorically used to describe the basic idea of the venture in the target industry. This leads to the following proposition.

Proposition 3: Entrepreneurs who lack prior experience in industries associated with the new venture are likely to extend argument constructions meta- 
phorically when they are initially speaking to others about it.

\section{THE MEDIATING INFLUENCE OF UNCERTAINTY AND LEGITIMACY}

While making sense about and identifying new opportunities for ventures plays a central role in the process of new venture creation, it is not sufficient simply to envision an opportunity. Rather, for a venture opportunity to succeed, entrepreneurs need to convince relevant others (e.g., investors and employees) publicly of the feasibility and legitimacy of the venture and, as a result, gain their support (Aldrich \& Fiol, 1994; Starr \& MacMillan, 1990; Zott \& Huy, 2007). Given that most start-ups or new ventures lack proven track records, entrepreneurs need, while speaking, to construct accounts that help explain, rationalize, and promote a new venture and reduce the uncertainty typically associated with it (Aldrich \& Fiol, 1994; Lounsbury \& Glynn, 2001). Their sensemaking has to demonstrate to others the feasibility of any new venture and its potential for wealth creation.

Entrepreneurs, as we have argued, will initially draw from their own experiences to induce, while speaking, the opportunity for a novel venture and will seek to gain initial feedback from others, without yet committing themselves publicly to a venture or a particular course of action (Alvarez \& Barney, 2007; Hite \& Hesterley, 2001). At the outset, entrepreneurs are likely to speak to a small circle of close contacts (e.g., Hite \& Hesterley, 2001), most stemming from preexisting social, family, or historical relationships (e.g., Hite \& Hesterley, 2001; Stam \& Elfring, 2008). They will, as we have argued, use analogies or metaphors to articulate basic images or scenes of both cause and effect, but with many essential elements initially undefined (Sarasvathy, 2001, 2004). Such images or scenes are further explored and possibly revisited as a result of communication with others (Alvarez \& Barney, 2007).

When such initial images and scenes evolve into a more determinate commitment, entrepreneurs need to convince other individuals (e.g., potential employees) and investors who have direct business or capital links to support the venture (Alvarez \& Barney, 2007; Mosey \& Wright, 2007). The broader range and diversity of people that entrepreneurs speak to may activate added pressures to make the venture understood and legitimate in the eyes of others (Hannon et al., 2007). Entrepreneurs will be motivated to resolve this uncertainty and to adapt their reasoning in such a way that they demonstrate efficacy. They may be prompted to elaborate or to replace the image or scene for the novel venture in an attempt to explain it to stakeholders. They may also be triggered to adapt their sensemaking so that their accounts make direct references to implications for growth (Baron \& Markman, 2000; Baum \& Locke, 2004; Chen, Yao, \& Kotha, 2009).

Specifically, in the early stages of a venture, entrepreneurs need to reduce stakeholders' uncertainty, at least in part with the goal of demonstrating the predictability and cognitive legitimacy of the venture (e.g., Aldrich \& Fiol, 1994; Zimmerman \& Zeitz, 2002). Predictability relates to uncertainty about the probability of the success of the new venture or uncertainty stemming from a lack of information about cause-effect relationships in a particular industry. This uncertainty primes the use of analogies and metaphors in an entrepreneur's speech to others (Aldrich \& Fiol, 1994; Lounsbury \& Glynn, 2001). In the absence of a performance track record that entrepreneurs can point to, they often rely on analogies or metaphors to provide an inductive rationale that projects a trajectory for the venture (Lounsbury \& Glynn, 2001).

Cognitive legitimacy refers to the comprehension and taken-for-grantedness of a new venture (e.g., Aldrich \& Fiol, 1994; Zimmerman \& Zeitz, 2002). When incentives for legitimacy are high, because of the absence of rival entrepreneurial ventures with similar innovations or of rival firms operating in the same industry, entrepreneurs often rely on analogies and metaphors to put the novel venture within a familiar frame of reference and to legitimize its existence (Horgadon \& Douglas, 2001; Lounsbury \& Glynn, 2001). As Lounsbury and Glynn argue, entrepreneurs need to "make the unfamiliar familiar by framing the new venture (often through metaphor and analogy) in terms that are understandable and thus legitimate" (2001: 549).

These two main factors (uncertainty and cognitive legitimacy), we argue, mediate the use of analogies and metaphors while entrepreneurs communicate about the venture to stakeholders in an effort to gain their behavioral support. Figure 1 depicts the overall process model of 
FIGURE 1

Entrepreneurial Sensemaking and the Venture Creation Process

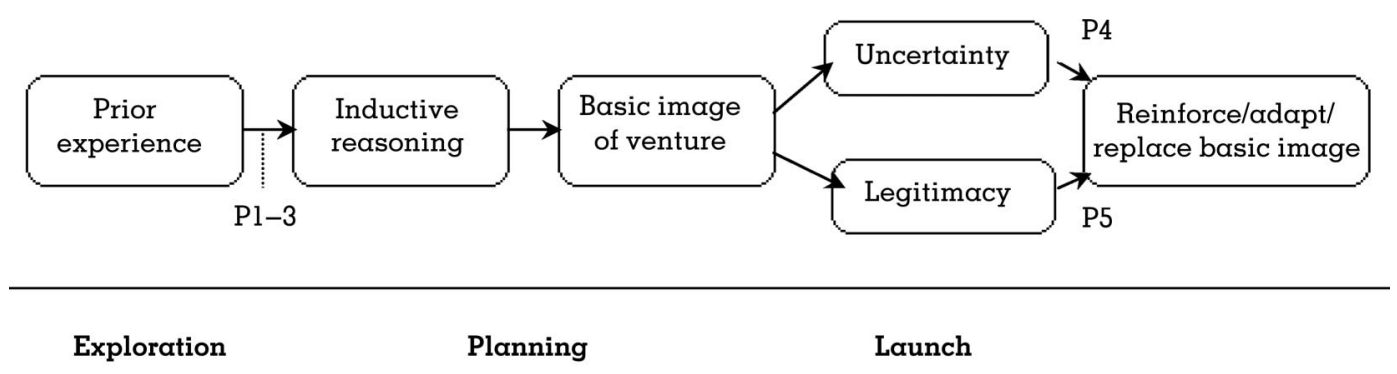

Venture creation process

entrepreneurial sensemaking during the early stages of venture creation, including the mediating role of uncertainty and legitimacy.

In line with Figure 1, we argue that entrepreneurs reinforce, adapt, or replace the initially induced image or scene of the venture, depending on the feedback of others and in response to stakeholder perceptions of uncertainty and the cognitive legitimacy of their ventures. Reinforcement is like to occur when the induced image or scene is easily comprehended, reduces uncertainty about the venture's predictability, and is perceived as legitimate by stakeholders (Zott \& Huy, 2007: 94-95). For example, when entrepreneurs can make relevant links to their past experiences with ventures in related industries or to certain competencies acquired through previous ventures, they can analogically refer to these as a way of strengthening trust in a venture in a novel industry and, hence, increasing its predictability (Martens et al., 2007; Zott \& Huy, 2007).

In the case of Magic, its analogical model of "customer-centric online shopping" was reinforced in all of its communications after the model had been quickly accepted by the market. One outside expert confirmed the success of these reinforcement tactics when he commented that "Magic has become the default name when you think of buying on the net" (Santos \& Eisenhardt, 2009: 651). While the venture was quickly understood and was seen as destined for success, the executives of Magic did encounter some customer insecurity surrounding the low legitimacy of online shopping at the time. In response, Magic slightly adapted its sensemaking by widely disseminating another story that metaphorically referred to U.S. history, portraying the founder as a "pioneer moving west" to "open up a new frontier" (Santos \& Eisenhardt, 2009: 651). This was meant to increase the legitimacy of the nascent market to customers and, in turn, the ability of the venture to profit from it.

Adaptation refers to a reformulation or elaboration of the induced image or scene for the venture. It is a process at the level of a previously articulated basic image or scene. It occurs when prior entrenched descriptions serve as an automatic base for the induction of a basic scene but are further extended and elaborated in response to a persistent need for efficacy and until uncertainty and legitimacy in the eyes of stakeholders are satisfied. Baker et al. illustrate the process of adaptation in their observation that, in interactions with employees, entrepreneurs added analogies or metaphors (e.g., of the venture organization as a "family") that they had "made up on the fly to make their fledgling firms seem comfortable and normal-that is, legitimate—to potential employees" (2003: 263). In turn, such social constructions "became part of employee expectations and the emerging culture of the organization after the people [had] joined the firm" (Baker et al., 2003: 263).

The example of Secret also illustrates the process of adaptation during the early stages of launching a venture. Initially, as mentioned, the model for the venture had been induced on the back of an argument construction that had, after a few iterations, shifted to the metaphor of security, or rather trust, in the case of border control. Secret's executives disseminated stories and organized events to convey its unique "trust identity" and intertwined it with a market for trust services (a conception that was distinct from competing market conceptions of selling security products). They also signaled their leadership by setting online certification stan- 
dards for this nascent market. Investors had accepted the image early on. Uncertainty about the legitimacy of the market, however, persisted in the eyes of customers; this prompted Secret's executives to adjust their projected identity by analogically "adding the template of a 'public utility' that conveyed the ubiquity and high reliability of a trusted service" (Santos \& Eisenhardt, 2009: 650). This adjustment helped them gain legitimacy for their venture and the nascent market. This elaborated vision also guided later decisions, such as which activities to pursue (Santos \& Eisenhardt, 2009: 650). In other words, as a result of interactions with stakeholders, these kinds of adapted images become "social constructs that guide subsequent actions of these entrepreneurs and others associated with an industry or market-including customers and suppliers" (Alvarez \& Barney, 2007: 15).

Replacement refers to the substitution of the initial induced image with an alternative analogy or metaphor in response to persistent uncertainty and low levels of legitimacy in the eyes of stakeholders. It refers to the process where entrepreneurs substitute, while speaking, the initial image and its associated elaborating elements toward stakeholders with "later verbal articulations [providing] a framework for developing shared understanding" (Hill \& Levenhagen, 1995: 1071). Haven, another venture studied by Santos and Eisenhardt (2009), is a good example of this process. Haven's founder had stumbled upon the nascent market of online marketplaces. He personally valued egalitarianism and fused these values into an identity for the venture using the metaphorical frame of "community," which led to an emphasis on how "friends" could connect, share information, and trade in a "safe neighborhood" (Santos \& Eisenhordt, 2009: 651). Although this identity was clear and understood within Haven itself, the team experienced some difficulties in explaining this to prospective customers. Thus, it decided to replace the community image with a more factual account of the venture's existence based on a balanced, fair marketplace for buyers and sellers. This approach failed, however, and led to a return to the "community identity," which was subsequently emphasized through the dissemination of a romantic and personal (albeit fictitious) story about the founding of the venture.

Generally speaking, the adaptation and replacement of initially induced images for a ven- ture are done to quell concerns about its predictability and legitimacy (Figure 1). As mentioned, this adjustment or correction process is likely to operate as a gradual process (Epley \& Gilovich, 2006) in which, based on the plausibility of the initial image for the venture and the ambiguity in the market, an adjustment away from the default inductive base is made until a satisfactory solution is reached (Goodman, 1955). Initially, entrepreneurs are likely to elaborate or extend the induced image by adding further analogies or metaphors. In the case of Secret, the additional public utility analogy blended coherently with the initial trust image and helped communicate the predictability of the venture to customers. These kinds of elaborations or extensions, providing they are coherent in terms of the underlying representation, may help tune communication about the feasibility of the venture toward specific stakeholders or audiences. Combinations of analogies and metaphors are possible because although exact interpretations may vary between stakeholders and audiences, their intuitions about the underlying representation tend to be largely consistent in terms of causes, individual roles, intentionality, and manner of actions (Gibbs \& O’Brien, 1990).

Besides addressing the uncertainty about a venture and its predictability, an entrepreneur's adjustments of the image for a venture may also be guided by assessments of the plausibility of the analogy or metaphor and its ability to confer legitimacy on the new venture. Douglas (1986) famously argued that new conventions, such as claimed new markets or ventures, gain institutional legitimacy on the back of a "naturalizing analogy"- $\alpha$ drawn parallel or association with another domain that sustains the novel convention by demonstrating its fit with the natural order. In her analysis, when the association with the other domain points to strong parallels with relations "found in the physical world, or in the supernatural world, or in eternity, anywhere, so long as it is not seen as a socially contrived arrangement" (Douglas, 1986: 48), the status and taken-for-granted nature of this source domain may by association justify the reasonableness of the new convention.

Recently, Hannan et al. (2007) argued that the grounds for legitimacy stem from the degree to which a venture (or indeed any other organization) is seen by a stakeholder audience as a 
default or prototypical member of an existing category or domain of understanding. This argument is akin to Glucksberg, McGlone, and Manfredi's (1997) account of analogies and metaphors as category-inclusion statements in which a new venture such as Magic is positioned as a central or prototypical instance of novel, ad hoc constructed categories, such as online shopping (Gentner et al., 2001). With such category-inclusion statements, potential categories are generated or invoked from the source of the comparison (e.g., offline shopping) while sets of modifiable dimensions are simultaneously identified in the topic (e.g., self-service shopping on the web). The interpretation of the legitimacy of the analogy or metaphor, thus, is a kind of negotiation between the category of understanding prototypically associated with the source and the dimensions of the described target. If the target is indeed judged by stakeholders to be a prototypical member of the ad hoc constituted category (i.e., online shopping), then the comparison is more likely to confer legitimacy.

The foregoing discussion leads to the following general propositions regarding the mediating influence of uncertainty and legitimacy on entrepreneurial sensemaking in interactions with stakeholders. Analogies and metaphors are reinforced, adapted, or replaced until uncertainty about the venture's predictability is satisfied and cognitive legitimacy is attained, at which point the motivation diminishes.

Proposition 4: The degree of uncertainty regarding the predictability of a venture in an industry mediates the likelihood that entrepreneurs will rely on their initial analogies or metaphors when speaking to others. A high level of uncertainty is associated with an adaptation or replacement-and a low level of uncertainty with a reinforcement-of these initial analogies or metaphors.

Proposition 5: The degree of cognitive legitimacy of a venture in an industry mediates the likelihood that entrepreneurs will rely on their initial analogies or metaphors when speaking to others. A low level of legitimacy is associated with an adaptation or replacement-and a high level of legit- imacy with a reinforcement-of their initial analogies or metaphors.

\section{DISCUSSION}

In this article we have elaborated a process theory of new venture creation that highlights the role of entrepreneurs' sensemaking to themselves and to others whose understanding and support are critical to a venture's success. We have argued that in the absence of a performance trajectory, entrepreneurs rely on inductive (analogical or metaphorical) reasoning to create and justify a rationale for a novel venture that accounts for its existence and garners the necessary support from relevant stakeholders and resource providers. We next discuss the implications for theory and research on entrepreneurship, sensemaking, and new venture creation.

\section{Contributions and Implications}

First, we believe this article illustrates the significant potential that exists for a focus on sensemaking (Taylor \& Van Every, 2000; Weick et al., 2005) to contribute to existing theories and concerns within entrepreneurship research. To date, research on entrepreneurial cognition and research on the institutionalization of novel ventures have tended to remain relatively selfreferential (e.g., Alvarez \& Barney, 2007), with a significant gap between them as a result of the rather different scholarly traditions and methods associated with positivist psychology and interpretive sociology (e.g., DiMaggio, 1997). Although this may have been necessary for each of these research streams to develop a strong set of theoretical and methodological principles (e.g., Baron \& Ward, 2004; Mitchell et al., 2002), we believe that it is time to integrate their insights into a more comprehensive and processual understanding of how entrepreneurs develop and explore ideas for a novel venture, plan and launch their ventures, and seek to acquire support and legitimacy to sustain and grow these ventures over time.

The sensemaking approach that we have elaborated in this paper focuses on how entrepreneurs, while speaking, construct meaning about novel ventures for themselves and others in the early stages of the venture creation process. This particular approach provides a fertile 
area for such integration, with its assumptions regarding the socially constructed nature of reality and its singular focus on the verbal speech acts through which entrepreneurs simultaneously envision and rationalize the potential for novel ventures. In developing our model, we have attempted to show not only the common threads that cut across the areas of entrepreneurial cognition and institutional theory but also how systematic, empirically useful theory can be derived from their integration. Specifically, we have combined determinants (prior experience and uncertainty about the predictability and legitimacy of a novel venture) derived from cognitive and institutional theory and have specified how together they impact the entrepreneurial process by which new ventures are imagined, developed, and sustained over time. Thus, we believe our work highlights that the connection between cognitive and institutional theory in entrepreneurship has significant potential for both theory development and empirical research.

A second implication involves the specification of varieties of inductive analogical and metaphorical reasoning about novel ventures. Scholars recognize induction as central not only to how entrepreneurs envision novel opportunities (e.g., Baker \& Nelson, 2005; Baron \& Ward, 2004; Sarasvathy, 2001, 2004; Sternberg, 2004) but also to how they legitimize those opportunities to others (e.g., Lounsbury \& Glynn, 200l; Zott \& Huy, 2007). Yet very little existing research on entrepreneurship has provided a theoretical specification of when and how entrepreneurs use specific analogical or metaphorical comparisons as an inductive anchor to reason about $a$ venture in a novel, unfamiliar industry. We address this shortcoming by defining the determinants and variety of analogical and metaphorical reasoning in venture creation processes. In so doing we contribute directly to central questions about how opportunities for a novel venture are identified or created (e.g., Alvarez \& Barney, 2007; Baron \& Ward, 2004) and how the institutionalization of a novel venture occurs over time (e.g., Lounsbury \& Glynn, 2001; Santos \& Eisenhardt, 2009). Our model extends the cognitive tradition by specifying the processes and conditions of inductive reasoning by which entrepreneurs envision opportunities for novel ventures. Within this tradition these processes have often been implied as invariant and auto- matic psychological processes (e.g., Baron \& Ensley, 2006) rather than directly theorized (Baron \& Ward, 2004; Ward, 2004). Further research, we suggest, can draw directly on the propositions on prior experience and inductive (analogical or metaphorical) reasoning to study the cognitive processes by which the opportunity for a novel venture is created or identified.

Our model also extends institutional research on entrepreneurship and begins to explain how and why, through inductive reasoning, the institutionalization of a venture may occur (e.g., Lounsbury \& Glynn, 2001; Phillips et al., 2004). Institutional research has been largely silent on how the content or structure of speech reflects and shapes the institutionalization process and how entrepreneurs, through inductively generated associations and arguments, establish shared understanding and legitimacy for their novel ventures (e.g., Santos \& Eisenhardt, 2009; Zott \& Huy, 2007). Such associations and arguments may be analogically connected to institutionalized standards and conventions in any given industry (Hannan et al., 2007) or to the past experiences of an entrepreneur, but they may also involve creative metaphorical comparisons or coherently blended images that provide the basis for institutionalization. In making these distinctions, we believe that we have enriched the institutional literature. Lounsbury and Glynn (2001) and Zimmerman and Zeitz (2002) argue that there is a limited understanding of the symbolic processes through which new ventures are framed as viable and legitimate businesses. By identifying varieties of inductive reasoning and by formalizing them into a set of propositions, we point to a number of ways to study the institutionalization of new ventures.

A third implication relates to the proposed process model of entrepreneurial sensemaking. This model adds to process studies of entrepreneurial action (McMullen \& Sheperd, 2006; Zott \& Huy, 2007) in that it theoretically links cognitive and symbolic activities performed by entrepreneurs across the early stages of setting up new ventures. As such, it is more widely applicable than studies that have focused on specific stages, such as the launch or initial public offering of a new venture (e.g., Chen et al., 2009; Martens et al., 2007). Underpinning the model is a theory of sensemaking as a socially situated process by which individuals construct meaning while speaking. This definition of sensemaking 
applies to the context of new ventures-where the demands of online sensemaking require that individual entrepreneurs think by speaking, meaning that conscious thought emerges in the act of speaking with others (Hill \& Levenhagen, 1995)—but potentially also extends to sensemaking in other social and organizational settings.

Existing research on sensemaking, however, largely separates individual cognition, or sensemaking, from symbolic "sensegiving" processes in social or organizational settings (see Maitlis \& Sonenshein, 2010; Weick et al., 2005). We argue instead that language and thought interpenetrate in context and that meaning develops as a result of interactions with others. In the classic case of the Mann Gulch disaster (Weick, 1993), for example, when the spotters on the aircraft had labeled the fire as a "10 o'clock fire," the firefighters on the ground committed themselves to this interpretation and believed it to be a fire that was relatively contained. According to Weick (1993: 635), they also reinforced and "rationalized this image until it was too late"-an analysis that points to the formative effect of language and to social validation in reifying the circumstances the firefighters faced. Another more recent study of the hijacking of United Airlines flight 93 (Quinn \& Worline, 2008: 501) demonstrates how people aboard the plane responded to this "shocking and incomprehensible" event by constructing a sensible narrative that allowed them to deliberate the action of collectively counterattacking the hijackers. The narrative evolved while people on the plane were phoning their close relatives and partners for approval and emotional support, which, in turn, gave the passengers the confidence to go ahead with their courageous counterattack (Quinn \& Worline, 2008).

Although settings of crisis and change are not necessarily the same as the early stages of venture creation, there are clear parallels across these sensemaking scenorios in the sense that individuals, drawing from their own experience and identity, construct meaning of inchoate circumstances, while speaking with others, and reinforce, replace, or adapt their sensemaking in the context of voiced or perceived social expectations. This particular formulation offers the potential for a more parsimonious perspective on sensemaking that, we argue, may benefit research. Over the past fifteen years, sensemak- ing has become an increasingly popular umbrella construct (Hirsch \& Levin, 1999) that has usurped divergent theoretical principles around, for example, cognitive dissonance, the autonomic nervous system, behavioral enactment, social identity, behavioral routines, emotions, speech acts, and escalation of commitment (e.g., Weick, 1995; Weick et al., 2005). Integration of these principles into a single construct is laudable, but it lacks specificity and provides broad, rather than specific, guidance to empirical research.

A fourth related and final implication concerns the empirical examination of speech and communication in entrepreneurship research. The constructs and propositions in our model can be readily connected to techniques for the identification and analysis of analogies and metaphors (e.g., Cornelissen, Oswick, Christensen, \& Phillips, 2008; Putnam \& Fairhurst, 2001) and their use in the context of entrepreneurial sensemaking (e.g., Lounsbury \& Glynn, 2001) $)^{1}$. For example, further research may systematically study argument constructions (Goldberg, 1995), which provide the inductive core around which entrepreneurs elaborate larger scenarios or narratives for their ventures. Such studies will buttress the arguments and analyses of the burgeoning tradition of interpretive research on entrepreneurial narratives (e.g., Martens et al., 2007).

We furthermore believe that a key strength of our theorizing is that it provides a potential foundation for empirical process studies of the proposed links between on entrepreneur's prior experience and speech, social contexts of speaking, and institutionalized discourses in on industry, using either a qualitative or quantitative research design. Each of the theorized links that we have elaborated and illustrated with case examples (Santos \& Eisenhardt, 2009) can provide the focus for intensive qualitative investigations that might serve to confirm or refute our arguments, as well as flesh out the details of these complex relationships. The model could

\footnotetext{
${ }^{1}$ We restrict our focus here to verbal analogies and metaphors. We acknowledge that inductive reasoning may also involve analogies or metaphors in other "modalities," including the drawing of pictorial images or the construction of prototypes or artefacts (e.g., Cornelissen et al., 2008), but this is beyond the scope of the paper. We thank one of the reviewers for providing this insight.
} 
also inform a quantitative examination of the dynamics of entrepreneurial speech and the institutionalization of ventures in an industry over time, with the propositions that we have developed forming the basis for a set of testable hypotheses. This would require the assembly of $a$ database of novel ventures in specific industries, speech acts of novice and experienced entrepreneurs, and the measurement of performance outcomes and the legitimacy of ventures over time. This database would need to be large enough to allow for systematic comparisons; such a study might easily be done in the form of a longitudinal study of novel ventures in a particular set of industries so that other factors might be at least partially controlled.

\section{Conclusion}

In this article we have theorized about how inductive reasoning through analogies or metaphors is central not only to how entrepreneurs envision an opportunity for a novel venture but also to the way in which they communicate about that venture so that it can be understood and made acceptable and legitimate in the eyes of key stakeholders. Connecting strands of cognitive and institutional research, we highlighted two determinants (prior experience and uncertainty about the predictability and legitimacy of a novel venture) that influence how entrepreneurs envision and rationalize the opportunity for a novel venture. These contributions can be used to reconceptualize and guide the study of how entrepreneurs imagine venture opportunities and of how they simultaneously develop and legitimize new ventures to exploit such opportunities.

\section{REFERENCES}

Aldrich, H. E., \& Fiol, M. C. 1994. Fools rush in: The institutional context of industry creation. Academy of Management Review, 19: 645-670.

Alvarez, S. A., \& Barney, J. 2007. Discovery and creation: Alternative theories of entrepreneurial action. Strategic Entrepreneurship Journal, 1: 11-26.

Baker, T., Miner, A.S., \& Eesley, D. T. 2003. Improvising firms: Bricolage, account giving and improvisational competencies in the founding process. Research Policy, 32: 255-276.

Baker, T., \& Nelson, R. E.. 2005. Creating something from nothing: Resource construction through entrepreneurial bricolage. Administrative Science Quarterly, 50: 329366.

Baron, R. A., 2000. Counterfactual thinking and venture formation: The potential effects of thinking about what might have been. Journal of Business Venturing, 15: 79-92.

Baron, R. A., \& Ensley, M. 2006. Opportunity recognition as the detection of meaningful patterns: Evidence from comparisons of novice and experienced entrepreneurs. Management Science, 52: 1331-1344.

Baron, R. A., \& Markman, G. D. 2000. Beyond social capital: How social skills can enhance entrepreneurs' success. Academy of Management Executive, 14(1): 106-116.

Baron, R. A., \& Ward, T. 2004. Expanding entrepreneurial cognition's toolbox: Potential contributions from the field of cognitive science. Entrepreneurship Theory and Practice, 28: 553-573.

Bartholomew, A., \& Mayer, M. 1992. Nomads of the present: Melucci's contribution to "new social movement" theory. Theory, Culture and Society, 9: 141-159.

Baum, J. R., \& Locke, E. A., 2004. The relationship of entrepreneurial traits, skill, and motivation to new venture growth. Journal of Applied Psychology, 89: 587-598.

Busenitz, L. W., \& Barney, J. B. 1997. Differences between entrepreneurs and managers in large organizations: Biases and heuristics in strategic decision-making. Journal of Business Venturing, 12: 9-30.

Cardon, M. S., Zietsma, C., Saparito, P., Matherne, B. P., \& Davis, C. 2005. A tale of passion: New insights into entrepreneurship from a parenthood metaphor. Journal of Business Venturing, 20: 23-45.

Chen, X. P., Yao, X., \& Kotha, S. 2009. Entrepreneur passion and preparedness in business plan presentations: A persuasion analysis of venture capitalists' funding decisions. Academy of Management Journal, 52: 199-214.

Cornelissen, J. P. 2005. Beyond compare: Metaphor in organization theory. Academy of Management Review, 30: 751-764.

Cornelissen, J. P., Oswick, C., Christensen, L. T., \& Phillips, N. 2008. Metaphor in organizational research: Context, modalities and implications for research. Organization Studies, 29: 7-22.

Creed, W. E. D., Langstraat, J., \& Scully, M. 2002. A picture of the frame: Frame analysis as technique and as politics. Organizational Research Methods, 5: 34-55.

Denrell, J., Fang, C., \& Winter, S. G. 2003. The economics of strategic opportunity. Strategic Management Journal, 24: 977-990.

DiMaggio, P. J. 1997. Culture and cognition. Annual Review of Sociology, 23: 263-287.

Dodd, S. 2000. Metaphors and meaning: A grounded cultural model of US entrepreneurship. Journal of Business Venturing, 17: 519-535.

Donnellon, A. 1986. Language and communication in organizations: Bridging cognition and behavior. In $\mathrm{H}$. P. Sims, Jr., \& D. A. Gioia (Eds.), The thinking organization: 136-164. San Francisco: Jossey-Bass. 
Douglas, M. 1986. How institutions think. Syracuse, NY: Syracuse University Press.

Edwards, D. 1997. Discourse and cognition. London: Sage.

Epley, N., \& Gilovich, T. 2006. The anchoring and adjustment heuristic: Why adjustments are insufficient. Psychological Science, 17: 311-318.

Farjoun, M. 2008. Strategy making, novelty and analogical reasoning-Commentary on Gavetti, Levinthal, and Rivkin (2005). Strategic Management Journal, 29: 10011016.

Fauconnier, G. 1997. Mappings in thought and language. Cambridge: Cambridge University Press.

Fauconnier, G. 2000. Methods and generalizations. In T. Janssen, \& G. Redeker (Eds.), Cognitive linguistics: Foundations, scope, and methodology: 95-127. The Hague: Mouton De Gruyter.

Fauconnier, G., \& Turner, M. 1998. Conceptual integration networks. Cognitive Science, 22: 133-187.

Fauconnier, G., \& Turner M. 2002. The way we think: Conceptual blending and the mind's hidden complexities. New York: Basic Books.

Garud, R., \& Karnøe, P. 2003. Bricolage vs. breakthrough: Distributed and embedded agency in technology entrepreneurship. Research Policy, 32: 277-300.

Gavetti, G., Levinthal D. A., \& Rivkin, J. W. 2005. Strategymaking in novel and complex worlds: The power of analogy. Strategic Management Journal, 26: 691-712.

Gavetti, G., \& Warglien, M. 2007. Recognizing the new: $A$ multi-agent model of analogy in strategic decisionmaking. Working paper No. 08-028, Harvard Business School, Boston.

Gentner, D. 1983. Structure mapping: A theoretical framework for analogy. Cognitive Science, 7: 155-170.

Gentner, D., Bowdle, B., Wolff, P., \& Boronat, C. 2001. Metaphor is like analogy. In D. Gentner, K. J. Holyoak, \& B. N. Kokinov (Eds.), The analogical mind: Perspectives from cognitive science: 199-253. Cambridge, MA: MIT Press.

Gentner, D., \& Clement, C. 1988. Evidence for relational selectivity in interpreting analogy and metaphor. In G. H. Bower (Ed.), The psychology of learning and motivation: 307-358. New York: Academic Press.

Gibbs, R. W., \& O'Brien J. E. 1990. Idioms and mental imagery: The metaphorical motivation for idiomatic meaning. Cognition, 36: 35-68.

Gioia, D. A. 1986. Symbols, scripts, and sensemaking: Creating meaning in the organizational experience. In $\mathrm{H}$. P. Sims, Jr., \& D. A. Gioia (Eds.), The thinking organization: 49-74. San Francisco: Jossey-Bass.

Gioia, D. A., \& Mehra, A. 1996. Sensemaking in organizations. Academy of Management Review, 21: 1226-1230.

Gioia, D. A., Thomas, J. B., Clark, S. M., \& Chittipeddi. K. 1994. Symbolism and strategic change in academia: The dynamics of sensemaking and influence. Organization Science, 5: 363-383.

Glucksberg, S., McGlone, M. S., \& Manfredi, D. 1997. Property attribution in metaphor comprehension. Journal of Memory and Language, 36: 50-67.

Goldberg, A. E. 1995. Constructions: A construction grammar approach to argument structure. Chicago: University of Chicago Press.

Goodman, N. 1955. Fact, fiction, and forecast. Cambridge, MA: Harvard University Press.

Grégoire, D. A., Corbett, A. C., \& McMullen, J. S. In press. The cognitive perspective in entrepreneurship: An agenda for future research. Journal of Management Studies.

Hannan, M. T., Pólos, L., \& Carroll, G. R. 2007. Logics of organization theory: Audiences, codes, and ecologies. Princeton, NJ: Princeton University Press.

Hargadon, A., \& Douglas, Y. 2001. When innovations meet institutions: Edison and the design of the electric light. Administrative Science Quarterly 46: 476-501.

Haunschild, P. R., \& Miner, A. S. 1997. Modes of interorganizational imitation: The effects of outcome salience and uncertainty. Administrative Science Quarterly, 4l: 472500 .

Hill, R., \& Levenhagen, M. 1995. Metaphors and mental models: Sensemaking and sensegiving in innovative and entrepreneurial activities. Journal of Management, 21: 1057-1074.

Hirsch, P., \& Levin, D. Z. 1999. Umbrella constructs versus validity police: A life cycle model. Organization Science, 10: $199-212$.

Hite, J. M., \& Hesterly, W. S. 2001. The evolution of firm networks. Strategic Management Journal, 22: 275-286.

Holland, J. H., Holyoak, K. J., Nisbett, R. E., \& Thagard, P. R. 1986. Induction: Processes of inference, learning and discovery. Cambridge, MA: MIT Press.

Hutchins, E. 2005. Material anchors for conceptual blends. Journal of Pragmatics, 37: 1555-1577.

Korunka, C., Frank, H., Luegar, M., \& Mugler, J. 2003. The entrepreneurial personality in the context of resources, environment, and the startup process-A configurational approach. Entrepreneurship Theory and Practice, 28: 2342.

Krueger, N. F., Reilly, M. D., \& Carsrud, A. L. 2000. Competing models of entrepreneurial intentions. Journal of Business Venturing, 15: 411-432.

Lakoff, G. 1993. The contemporary theory of metaphor. In A. Ortony, (Ed.), Metaphor and thought (2nd ed.): 202-251. Cambridge: Cambridge University Press.

Lakoff, G., \& Johnson, M. 1980. Metaphors we live by. Chicago: University of Chicago Press.

Lakoff, G., \& Johnson, M. 1999. Philosophy in the flesh: The embodied mind and its challenge to Western thought. New York: Basic Books.

Langacker, R. W. 1991. Foundations of cognitive grammar. Volume II: Descriptive applications. Stanford, CA: Stanford University Press.

Lounsbury, M., \& Glynn, M. 2001. Cultural entrepreneurship: Stories, legitimacy, and the acquisition of resources. Strategic Management Journal, 22: 545-564. 
Maitlis, S., \& Sonenshein, S. 2010. Sensemaking in crisis and change: Inspiration and insights from Weick (1988). Journal of Management Studies, 47: 551-580.

March, J. G., \& Olsen, J. 1989. Rediscovering institutions: The organizational basis of politics. New York: Free Press.

Martens, M. L., Jennings, J. E., \& Jennings, P. D. 2007. Do the stories they tell get them the money they need? The role of entrepreneurial narratives in resource acquisition. Academy of Management Journal, 50: 1107-1132.

McMullen, J., \& Shepherd, D. 2006. Entrepreneurial action and the role of uncertainty in the theory of the entrepreneur. Academy of Management Review, 31: 132-152.

Mitchell, R. K., Busenitz, T., Lant, P. P., \& McDougall, E. A. 2002. Towards a theory of entrepreneurial cognition: Rethinking the people side of entrepreneurship. Entrepreneurship Theory and Practice, 27: 93-104.

Mitchell, R. K., Smith, J. B., Seawright, K. W., \& Morse, E. A. 2000. Cross-cultural cognitions and the venture creation decision. Academy of Management Journal, 43: 974-993.

Mosey, S., \& Wright, M. 2007. From human capital to social capital: A longitudinal study of technology-based academic entrepreneurs. Entrepreneurship Theory and Practice, 31: 909-935.

Nicholson, L., \& Anderson, A. 2005. News and nuances of the entrepreneurial myth and metaphor: Linguistic games in entrepreneurial sense-making and sense-giving. Entrepreneurship Theory and Practice, 29: 153-172.

Nisbett, R. E., \& Ross, L. D. 1980. Human inference: Strategies and shortcomings of social judgment. Englewood Cliffs, NJ: Prentice-Hall.

Phillips, N., Lawrence, T. B., \& Hardy, C. 2004. Discourse and institutions. Academy of Management Review, 29: 635-652.

Putnam, L. L., \& Fairhurst, G. T. 2001. Discourse analysis in organizations. In F. M. Jablin \& L. L. Putnam (Eds.), The new handbook of organizational communication: 78136. Newbury Park, CA: Sage.

Quinn, R., \& Dutton, J. 2005. Coordination as energy-inconversation: A process theory of organizing. Academy of Management Review, 30: 38-57.

Quinn, R., \& Worline, M. C. 2008. Enabling courageous collective action: Conversations from United Airlines flight 93. Organization Science, 19: 497-516.

Rao, H. 1994. The social construction of reputation: Certification contests, legitimation and the survival of organizations in the American automobile industry 1895-1912. Strategic Management Journal, 13: 29-44.

Rindova, V., Becerra, M., \& Contrado, I. 2004. Enacting competitive wars: Actions, language games, and market consequences. Academy of Management Review, 29: 670-687.

Santos, F. M., \& Eisenhardt, K. M. 2009. Constructing markets and shaping boundaries: Entrepreneurial power in nascent fields. Academy of Management Journal, 52: 643-671.

Sarasvathy, S. D. 2001. Causation and effectuation: Toward a theoretical shift from economic inevitability to entrepreneurial contingency. Academy of Management Review, 26: $243-288$.
Sarasvathy, S. D. 2004. Making it happen: Beyond theories of the firm to theories of firm design. Entrepreneurship Theory and Practice, 28: 519-531.

Shane, S. A. 2000. Prior knowledge and the discovery of entrepreneurial opportunities. Organization Science, 11: $448-469$.

Shane, S. A. 2003. A general theory of entrepreneurship: The individual-opportunity nexus. Cheltenham, UK: Elgar.

Slobin, D. 1987. Thinking for speaking. Proceedings of the Thirteenth Annual Meeting of the Berkeley Linguistics Society: 435-445.

Sloman, S. A., \& Lagnado, D. 2005. The problem of induction. In K. Holyoak \& R. Morrison (Eds.), The Cambridge handbook of thinking and reasoning: 95-116. New York: Cambridge University Press.

Stam, W., \& Elfring, T. 2008. Entrepreneurial orientation and the performance of high-technology ventures: The moderating role of intra- and extra-industry social capital. Academy of Management Journal, 51: 97-111.

Starr, J. A., \& MacMillan, I. C. 1990. Resource cooptation via social contracting: Resource acquisition strategies for new ventures. Strategic Management Journal, 11: 79-92.

Sternberg, R. J. 2004. Successful intelligence as a basis for entrepreneurship. Journal of Business Venturing, 19: 189201.

Strang, D., \& Meyer, J. W. 1993. Institutional conditions for diffusion. Theory and Society, 22: 487-511.

Taylor, J. R., \& Van Every, E. 2000. The emergent organization: Communication as its site and surface. Mahwah, NJ: Lawrence Erlbaum Associates.

Terlaak, A., \& Gong, Y. 2008. Vicarious learning and inferential accuracy in adoption processes. Academy of Management Review, 33: 846-868.

Tetlock, P. E. 2000. Cognitive biases and organizational correctives: Do both disease and cure depend on the ideological beholder? Administrative Science Quarterly, 45: 293-326.

Tetlock, P. E., \& Manstead, A. S. R. 1985. Impression management versus intrapsychic explanations in social psychology: A useful dichotomy? Psychological Review, 92: 59-77.

Ward, T. B. 2004. Cognition, creativity, and entrepreneurship. Journal of Business Venturing, 19: 173-188.

Weber, K. 2005. A toolkit for analyzing corporate cultural toolkits. Poetics, 33: 227-252.

Weber, K., \& Glynn, M. A. 2006. Making sense with institutions: Context, thought and action in Karl Weick's theory. Organization Studies, 27: 1639-1660.

Weber, K., Heinze, K. L., \& DeSoucey, M. 2008. Forage for thought: Mobilizing codes in the movement for grass-fed meat and dairy products. Administrative Science Quarterly, 53: 529-567.

Weick, K. E. 1993. The collapse of sensemaking in organizations: The Mann Gulch disaster. Administrative Science Quarterly, 38: 628-652.

Weick, K. E. 1995. Sensemaking in organizations. Thousand Oaks, CA: Sage. 
Weick, K. E., Sutcliffe, K. M., \& Obstfeld, D. 2005. Organizing and the process of sensemaking. Organization Science, 16: $409-421$.

Zilber, T. B. 2006. The work of the symbolic in institutional processes: Translations of rational myths in Israeli hitech. Academy of Management Journal, 49: 279-301.
Zimmerman, M. A., \& Zeitz, G. J. 2002. Beyond survival: Achieving new venture growth by building legitimacy. Academy of Management Review, 27: 414-431.

Zott, C., \& Huy, Q. N. 2007. How entrepreneurs use symbolic management to acquire resources. Administrative Science Quarterly, 52: 70-105.

Joep P. Cornelissen (J.Cornelissen@leeds.ac.uk) is a professor in corporate communication at Leeds University Business School, the University of Leeds. He received his Ph.D. from the Manchester Metropolitan University (UK). His current research focuses on narratives and processes of framing in the context of entrepreneurship and organizational change.

Jean S. Clarke (J.S.Clarke@lubs.leeds.ac.uk) is a lecturer in entrepreneurship at Leeds University Business School, the University of Leeds. She received her Ph.D. from the University of Leeds (UK). Her research interests include narrative, metaphor, and visual symbols in entrepreneurship and legitimacy creation. 
Copyright of Academy of Management Review is the property of Academy of Management and its content may not be copied or emailed to multiple sites or posted to a listserv without the copyright holder's express written permission. However, users may print, download, or email articles for individual use. 